\title{
High-temperature inhibitors of stainless steel corrosion in sulfuric acid solutions
}

\author{
Ya.G. Avdeev, ${ }^{1 *}$ D.S. Kuznetsov, ${ }^{2}$ M.V. Tyurina, ${ }^{1}$ S.V. Oleynik, ${ }^{2}$ \\ and M.A. Chekulaev ${ }^{1}$ \\ ${ }^{1}$ K.E. Tsiolkovsky Kaluga state university, Stepana Razina str. 26, Kaluga, 248023 \\ Russian Federation \\ ${ }^{2}$ A.N. Frumkin Institute of Physical Chemistry and Electrochemistry, Russian Academy of \\ Sciences, Leninsky pr. 31, Moscow, 119071 Russian Federation \\ *E-mail: avdeevavdeev@mail.ru
}

\begin{abstract}
The corrosion of chromium-nickel steel $08 \mathrm{Kh} 18 \mathrm{~N} 10 \mathrm{~T}$ in $2 \mathrm{M} \mathrm{H}_{2} \mathrm{SO}_{4}$ has been studied in a broad temperature range, $t=0-200^{\circ} \mathrm{C}$. Under these conditions, the metal corrosion is enhanced with an increase in $t$ to reach $9.7 \mathrm{~kg} /\left(\mathrm{m}^{2} \cdot \mathrm{h}\right)$ at $200^{\circ} \mathrm{C}$. It has been shown that a formulation of IFKhAN-92 inhibitor (a substituted triazole) with KI in a molar ratio of $1: 1$ protects this steel in $2 \mathrm{M} \mathrm{H}_{2} \mathrm{SO}_{4}$ at temperatures up to $140^{\circ} \mathrm{C}$, inclusive. The threecomponent mixture of IFKhAN-92, KI and urotropine $(1: 1: 4)$ is more promising in this respect, as it efficiently inhibits corrosion at temperatures up to $180^{\circ} \mathrm{C}$ and allows the protective effect to be maintained for at least $8 \mathrm{~h}$. This formulation also reliably protects low-carbon steel 20 in $2 \mathrm{M} \mathrm{H}_{2} \mathrm{SO}_{4}$ at temperatures up to $180^{\circ} \mathrm{C}$, inclusive; what is more, corrosion slows down with time in the presence of this mixture.
\end{abstract}

Key words: high-temperature acid corrosion, corrosion inhibitors, stainless steel, triazoles.

Received: December 26, 2016. Published: January 27, 2017.

doi: $\underline{10.17675 / 2305-6894-2017-6-1-4}$

\section{Introduction}

Solutions of mineral acids that are used for acidic treatment of oil- and water-bearing beds, removal of scale from metal surfaces, and cleaning of mineral deposits from inside surfaces of pipelines and equipment are of importance among the most corrosive industrial environments. In practice, inhibitory protection of metal structures in mineral acid solutions is mainly performed by organic compounds such as amines, quarternary ammonium salts, as well as pyridine and quinoline derivatives that are generally efficient up to $t=80^{\circ} \mathrm{C}$ only. Unfortunately, the vast majority of such inhibitors fail to meet the technological and ecological requirements of modern industries, where acid solutions contacting a metal can be heated to temperatures of $100^{\circ} \mathrm{C}$ or higher, while compounds used for metal corrosion protection should be, whenever possible, harmless for humans and for the environment. Creation of inhibitors capable of metal protection in acid solutions at 
$\geq 80^{\circ} \mathrm{C}$ (high-temperature corrosion inhibitors) is necessary for the oil and gas industry where hydrochloric acid treatment of oil beds with elevated temperatures at the well bottom is needed more and more often. It becomes possible to intensify metal etching and removal of mineral deposits by considerably increasing the temperatures of the acid solutions used in these operations.

Steel protection in mineral acid solutions under high-temperature corrosion conditions presents considerable technological difficulties due to the extreme corrosivity of these media. For example, according to N.I. Podobaev [1], the corrosion rate $(k)$ of St1 steel (composition, mass\%: $\mathrm{C} 0.07$; $\mathrm{P} 0.022$; $\mathrm{S} 0.027$; $\mathrm{Si} 0.02$ ) in $4 \mathrm{M} \mathrm{HCl}$ at $250^{\circ} \mathrm{C}$ was found to be $c a .48 \mathrm{~kg} /\left(\mathrm{m}^{2} \cdot \mathrm{h}\right)$ (the corrosion test duration was $\left.\tau=3 \mathrm{~min}\right)$. Even under "milder" conditions in $2 \mathrm{M} \mathrm{HCl}$ at $160^{\circ} \mathrm{C}$ and with longer exposure $(\tau=30 \mathrm{~min})$, the $k$ of steel 20 reaches $12 \mathrm{~kg} /\left(\mathrm{m}^{2} \cdot \mathrm{h}\right)[2]$.

The use of corrosion inhibitors is the only acceptable method for steel protection from corrosion under these conditions. The most common formulations recommended for these media contain unsaturated organic compounds [3-9]. In fact, the use of nitrogencontaining inhibitors (BA-6, PKU) in the presence of $\mathrm{Sn}^{2+}, \mathrm{Cr}^{3+}$ cations and $\mathrm{I}^{-}$anions as additives makes it possible to use hex-1-in-3-ol and propargyl alcohol to protect St1 steel in $4 \mathrm{M} \mathrm{HCl}$ at temperatures up to $250^{\circ} \mathrm{C}$ [1]. A similar formulation was patented by B.R. Keeney and J.W. Johnson [10] who stated that formulations $(0.025-25 \mathrm{~g} / \mathrm{l})$ comprising acetylenic alcohols, nitrogen-containing compounds and $\mathrm{CuI}$ are efficient inhibitors of steel corrosion in $\mathrm{HCl}, \mathrm{H}_{2} \mathrm{SO}_{4}, \mathrm{HF}, \mathrm{H}_{3} \mathrm{CCOOH}$ and in their mixtures at $t \leq$ $230^{\circ} \mathrm{C}$. Instead of acetylenic alcohols, the mercapto acetylene derivative of the following general formula can be used:

$$
\mathrm{HC} \equiv \mathrm{C}-\mathrm{R}-\mathrm{S}-\mathrm{R}-\mathrm{C} \equiv \mathrm{CH}
$$

It is suggested to use primary, secondary and tertiary amines containing $\mathrm{C}_{2}-\mathrm{C}_{6}$ hydrocarbon groups or pyridine derivatives as nitrogen-containing compounds. M.L. Walker [11] reported formulations for the protection of N80 steel (composition, mass\%: $\mathrm{C}$ 0.34-0.38; Si 0.20-0.35; $\mathrm{Mn} \mathrm{1.45-1.7;} \mathrm{P}$ up to 0.02; $\mathrm{S}$ up to 0.015; $\mathrm{Cr}$ up to 0.15; $\mathrm{V} 0.11-0.16$ ) in $\mathrm{HCl}, \mathrm{HCl}+\mathrm{HF}, \mathrm{H}_{2} \mathrm{SO}_{4}, \mathrm{H}_{3} \mathrm{CCOOH}$, and $\mathrm{HCOOH}$ solutions at $t \leq$ $260^{\circ} \mathrm{C}$. The formulations contain an acetylenic alcohol (5-35\%), a quaternary ammonium salt, an aromatic hydrocarbon, and a soluble antimony compound.

A formulation comprising various acetylenic alcohols, phenyl vinyl ketone, KI and $\mathrm{HCOOH}$ was recommended for the protection of N80 and J55 carbon steels (composition, mass\%: $\mathrm{C}$ 0.34-0.39; Si 0.20-0.35; Mn 1.25-1.5; $\mathrm{P}$ up to 0.02; $\mathrm{S}$ up to 0.015; $\mathrm{Cr}$ up to 0.15; $\mathrm{Ni}$ up to 0.20; $\mathrm{Cu}$ up to 0.20) and L80 chromium stainless steel (composition, mass\%: C 0.15-0.20; Si up to 1.00; Mn 0.25-1.0; P up to 0.02; S up to 0.010; Cr 12.014.0; $\mathrm{Ni}$ up to 0.20 ; $\mathrm{Cu}$ up to 0.20 ) in $\mathrm{HCl}$ solutions at $t \leq 150^{\circ} \mathrm{C}$ [12]. Formulations based on cinnamic aldehyde and a quarternary ammonium salt are used on the same steels at temperatures up to $120^{\circ} \mathrm{C}[12,13]$. 
The patent [14] reports data on the protection of $\mathrm{N} 80$ steel in $15-28 \% \mathrm{HCl}$ containing $\mathrm{KI}(1-2 \%)$ and $\mathrm{HCOOH}$ additives at $150^{\circ} \mathrm{C}$ by mixtures of phenylalkenylketones with alkyl- or alkylarylquinolinium salts. R.J. Jasinski and W.W. Frenier [15] recommend to protect steels containing more than $9 \% \mathrm{Cr}$ in $15 \% \mathrm{HCl}$ and its mixtures with $\mathrm{HF}(120-$ $250^{\circ} \mathrm{C}$ ) using formulations of phenylalkenylketones or substituted cinnamic aldehydes with derivatives of nitrogen-containing heterocycles (alkylpyridinium and alkylquinolinium salts). To enhance the protective action of these mixtures, the effects of $\mathrm{Bi}$ (III) and $\mathrm{Sb}$ (III) compounds soluble in acidic media, as well as $\mathrm{CuCl}$, on this effect were studied. Furthermore, the protective effect of the mixtures was enhanced by addition of KI or $\mathrm{HCOOH}$.

The broad practical application of unsaturated organic compounds is limited by their low thermal stability, liability to resinification in acidic solutions, and high toxicity. These drawbacks are not characteristic of the relatively new group of corrosion inhibitors, viz., triazoles, that have high stability against acids and thermal stability. Furthermore, they are capable of chemisorption on the surface of a corroding metal resulting in formation of protective inhibitor films [16-19]. For example, the formulation that we developed [2] on the basis of IFKhAN-92 inhibitor, a 3-substituted 1,2,4-triazole, makes it possible to protect steel 20 in $2-6 \mathrm{M} \mathrm{HCl}$ at $t \leq 160^{\circ} \mathrm{C}$.

Sulfuric acid solutions have been less thoroughly studied under high-temperature corrosion conditions. Like hydrochloric acid solutions, they are highly corrosive: at $140^{\circ} \mathrm{C}$, the $k$ of St3 steel (composition, mass\%: C 0.14-0.22; Mn 0.40-0.65; Si 0.15-0.30) reaches $3.8 \mathrm{~kg} /\left(\mathrm{m}^{2} \cdot \mathrm{h}\right)$ [20], while at $200^{\circ} \mathrm{C}$ for steel 20 (composition, mass\%: $\mathrm{C} 0.17-0.24$; Si $0.17-0.37$; Mn 0.35-0.65; $\mathrm{Ni}$ up to 0.3; $\mathrm{S}$ up to 0.04; $\mathrm{P}$ up to 0.035; $\mathrm{Cr}$ up to 0.25 ; $\mathrm{Cu}$ up to 0.3 ; As up to 0.08$), k=15 \mathrm{~kg} /\left(\mathrm{m}^{2} \cdot \mathrm{h}\right)[21,22]$. Formulations of IFKhAN-92 with KI [20-22] and $\mathrm{KBr}[21,22]$ possess unique properties in the protection of low-carbon steels in $\mathrm{H}_{2} \mathrm{SO}_{4}$ solutions at $t \geq 100^{\circ} \mathrm{C}$.

The literature available to us contains no information on the high-temperature corrosion of stainless steels, an important group of structural materials, in $\mathrm{H}_{2} \mathrm{SO}_{4}$ solutions. Our previous studies [23-25] on the corrosion behavior of chromium-nickel stainless steels in this medium at $t \leq 100^{\circ} \mathrm{C}$ allow us to assume that their stability is low under these conditions.

In view of the above, it seems worthwhile to study the corrosion of chromium-nickel stainless steel $08 \mathrm{Kh} 18 \mathrm{~N} 10 \mathrm{~T}$ in $\mathrm{H}_{2} \mathrm{SO}_{4}$ solutions in the range of $t=0-200^{\circ} \mathrm{C}$ and develop inhibitor formulations for its protection under these conditions. As the basis for the creation of composite inhibitors, we studied IFKhAN-92, whose mixtures with KI considerably hinder the corrosion of chromium-nickel steels in $\mathrm{H}_{2} \mathrm{SO}_{4}$ solutions at $t \leq$ $100^{\circ} \mathrm{C}$ [23-25] and the corrosion of low-carbon steel at $t \leq 200^{\circ} \mathrm{C}$ [20-22]. It is important to estimate the ability of formulations that we developed for the protection of stainless steels to inhibit the corrosion of low-carbon steels as well. 


\section{Experimental procedure}

High-temperature corrosion tests $\left(t=120-200^{\circ} \mathrm{C}\right)$ were carried out in a Huber autoclave (Finland) (the accuracy of temperature control was $\pm 3^{\circ} \mathrm{C}$ ). A cylindrical sample (15$50 \mathrm{~mm}$ long, depending on the metal corrosion rate, and $18 \mathrm{~mm}$ in diameter) of 08X18H10T steel (composition, mass\%: C 0.08; Cr 17-19; Ni 9-11; Si 0.8; Mn up to 2; S up to 0.02 ; $\mathrm{P}$ up to $0.035 ; \mathrm{Cu}$ up to 0.3 ; $\mathrm{Ti}$ up to 0.7 ) was placed into a quartz vessel containing $100 \mathrm{ml}$ of $2 \mathrm{M} \mathrm{H}_{2} \mathrm{SO}_{4}$. The base duration of the tests was 30,60, or $120 \mathrm{~min}$. The corrosion tests at $t=0-100^{\circ} \mathrm{C}$ were carried out by a similar technique in temperaturecontrolled corrosion vessels. The tests at $t=120-200^{\circ} \mathrm{C}$ were carried out in an autoclave using the following technique. A specimen was placed into an acid solution at $t=100^{\circ} \mathrm{C}$, heated to a required temperature, kept for 40,70 or $130 \mathrm{~min}$ at that temperature, and cooled to $104^{\circ} \mathrm{C}$. In order to take the specimen mass loss during autoclave heating and cooling into account, the tests were duplicated with exposure for $10 \mathrm{~min}$ at the corresponding temperatures. The corrosion rates for 30,60 , or 120 min periods were calculated from the difference between the specimen mass loss after 40, 70, or 130 minute exposures in the autoclave at the corresponding temperature and the mass loss after a 10-minute exposure.

The same technique was used in the corrosion tests of low-carbon steel 20 (flat specimens, $20 \mathrm{~mm} \times 20 \mathrm{~mm} \times 3 \mathrm{~mm}$ ) in the $\mathrm{H}_{2} \mathrm{SO}_{4}$ solution.

The specimens were cleaned on an abrasive disc (ISO 9001, 60 grit) and degreased with acetone prior to each experiment. Due to the low solubility of IFKhAN-92, it was added to $\mathrm{H}_{2} \mathrm{SO}_{4}$ solutions as a solution in ethanol. The resulting ethanol concentration in the pickling solution was $0.24 \mathrm{~mol} / \mathrm{l}$.

The efficiency of inhibitors was estimated from the inhibition coefficient, $\gamma=k_{0} / k_{\text {in }}$, where $k_{0}$ and $k_{\text {in }}$ are the corrosion rates in the non-inhibited solution and in the solution with the additive being studied, respectively. In order to estimate quantitatively the effect of additives on IFKhAN-92, the mutual influence coefficients of the mixture components were calculated [26]:

$$
K_{m}=\frac{\gamma_{m i x}}{\prod_{i=1}^{m} \gamma_{i}}
$$

where $\gamma_{\text {mix }}$ is the corrosion inhibition coefficient for the inhibitor mixture and $\prod_{i=1}^{m} \gamma_{i}$ is the product of the corrosion inhibition coefficients for the individual mixture components. At $K_{m}<1$, the protective effects of the inhibitor components are mutually reduced; at $K_{m}=1$, it has an additive nature; and it is only at $K_{m}>1$ that a mutual enhancement of protection by the mixture components is observed. 


\section{Experimental results and discussion}

$08 \mathrm{Kh} 18 \mathrm{~N} 10 \mathrm{~T}$ steel is rather resistant in cold $2 \mathrm{M} \mathrm{H}_{2} \mathrm{SO}_{4}\left(t=0^{\circ} \mathrm{C}\right)$ : the maximum observed $k$ is $0.34 \mathrm{~g} /\left(\mathrm{m}^{2} \cdot \mathrm{h}\right)$. However, the corrosion of steel systematically accelerates with an increase in $t$ and, according to the data of $0.5 \mathrm{~h}$ tests, it reaches $0.3 \mathrm{~kg} /\left(\mathrm{m}^{2} \cdot \mathrm{h}\right)$ at $80^{\circ} \mathrm{C}$, $0.7 \mathrm{~kg} /\left(\mathrm{m}^{2} \cdot \mathrm{h}\right)$ at $100^{\circ} \mathrm{C}$, and $9.7 \mathrm{~kg} /\left(\mathrm{m}^{2} \cdot \mathrm{h}\right)$ at $200^{\circ} \mathrm{C}($ Figure 1$)$.

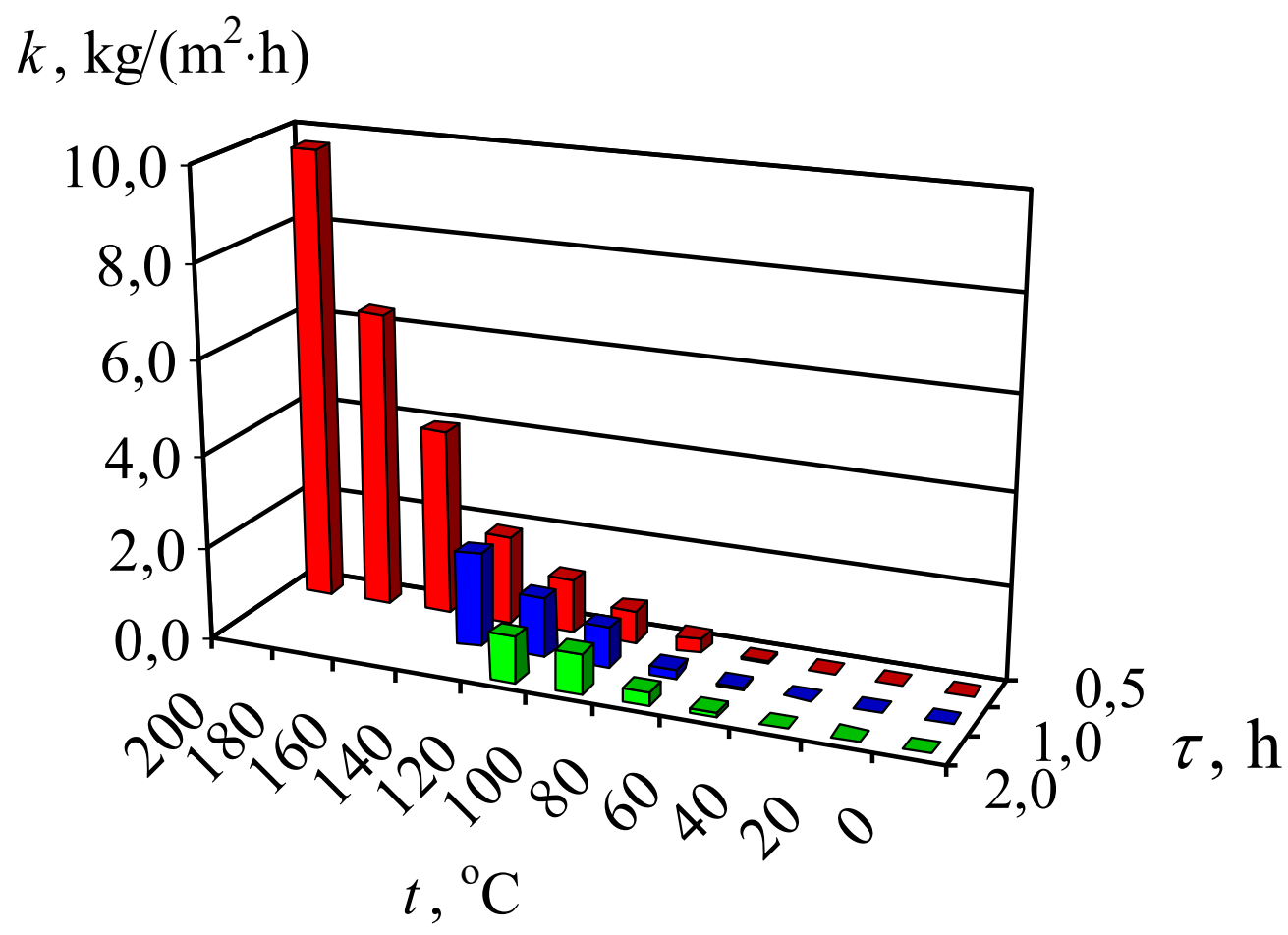

Figure 1. Corrosion rates of $08 \mathrm{Kh} 18 \mathrm{~N} 10 \mathrm{~T}$ steel in $2 \mathrm{M} \mathrm{H}_{2} \mathrm{SO}_{4}$ at various temperatures.

The equimolar mixture of IFKhAN-92 and KI that we previously developed [23-25] for the protection of stainless steels in sulfuric acid media efficiently protects the metal in $2 \mathrm{M} \mathrm{H}_{2} \mathrm{SO}_{4}$ at rather low concentrations $\left(C_{\text {mix }}=5 \mathrm{mM}\right)$ at $t \leq 140^{\circ} \mathrm{C}$, where $k \leq 10 \mathrm{~g} /\left(\mathrm{m}^{2} \cdot \mathrm{h}\right)$ (Table 1). However, a further $t$ increase by $20^{\circ} \mathrm{C}$ abruptly decreases $\gamma 3$-fold (in $0.5 \mathrm{~h}$ tests). Furthermore, corrosion increases with time in the presence of the inhibitor formulation to reach $162 \mathrm{~g} /\left(\mathrm{m}^{2} \cdot \mathrm{h}\right)$. To improve steel protection in $2 \mathrm{M} \mathrm{H}_{2} \mathrm{SO}_{4}$, the content of this inhibitor mixture in the solution was increased to $C=10 \mathrm{mM}$. This allowed us to improve steel protection in $2 \mathrm{M} \mathrm{H}_{2} \mathrm{SO}_{4}$ at $t>100^{\circ} \mathrm{C}$. However, even in this case, according to the data of $2 \mathrm{~h}$ tests, $k=117 \mathrm{~g} /\left(\mathrm{m}^{2} \cdot \mathrm{h}\right)$ at $t=160^{\circ} \mathrm{C}$, which does not allow us to expect that this formulation would be efficient at higher temperatures. 
Table 1. Corrosion rates $\left(k, \mathrm{~g} /\left(\mathrm{m}^{2} \cdot \mathrm{h}\right)\right)$ and corrosion inhibition coefficients $(\gamma)$ of $08 \mathrm{Kh} 18 \mathrm{~N} 10 \mathrm{~T}$ steel in $2 \mathrm{M} \mathrm{H}_{2} \mathrm{SO}_{4}$ at various temperatures.

\begin{tabular}{|c|c|c|c|c|c|c|}
\hline \multirow{3}{*}{ Inhibitor } & \multicolumn{6}{|c|}{ Test duration } \\
\hline & \multicolumn{2}{|c|}{$0.5 \mathrm{~h}$} & \multicolumn{2}{|c|}{$1.0 \mathrm{~h}$} & \multicolumn{2}{|c|}{$2.0 \mathrm{~h}$} \\
\hline & $\boldsymbol{k}$ & $\gamma$ & $\boldsymbol{k}$ & $\gamma$ & $\boldsymbol{k}$ & $\gamma$ \\
\hline \multicolumn{7}{|c|}{$0^{\circ} \mathrm{C}$} \\
\hline $2.5 \mathrm{mM}$ IFKhAN-92 + $2.5 \mathrm{mM} \mathrm{KI}$ & $-*$ & - & $-*$ & - & $-*$ & - \\
\hline $\begin{array}{c}2.5 \mathrm{mM} \text { IFKhAN-92 + } 2.5 \mathrm{mM} \mathrm{KI} \\
+10 \mathrm{mM} \text { urotropine }\end{array}$ & -* & - & -* & - & -* & - \\
\hline \multicolumn{7}{|c|}{$20^{\circ} \mathrm{C}$} \\
\hline $2.5 \mathrm{mM}$ IFKhAN-92 + $2.5 \mathrm{mM} \mathrm{KI}$ & -* & - & 0.04 & 88 & 0.02 & 170 \\
\hline $\begin{array}{c}2.5 \mathrm{mM} \text { IFKhAN-92 + } 2.5 \mathrm{mM} \mathrm{KI} \\
+10 \mathrm{mM} \text { urotropine }\end{array}$ & -* & - & -* & - & $-*$ & - \\
\hline \multicolumn{7}{|c|}{$40^{\circ} \mathrm{C}$} \\
\hline 2.5 mM IFKhAN-92 + 2.5 mM KI & $-*$ & - & 0.07 & 300 & 0.10 & 170 \\
\hline $\begin{array}{c}2.5 \mathrm{mM} \text { IFKhAN-92 + } 2.5 \mathrm{mM} \mathrm{KI} \\
+10 \mathrm{mM} \text { urotropine }\end{array}$ & -* & - & -* & - & 0.02 & 850 \\
\hline \multicolumn{7}{|c|}{$60^{\circ} \mathrm{C}$} \\
\hline $2.5 \mathrm{mM}$ IFKhAN-92 + $2.5 \mathrm{mM} \mathrm{KI}$ & 0.53 & 106 & 0.55 & 115 & 0.46 & 189 \\
\hline $\begin{array}{c}2.5 \mathrm{mM} \text { IFKhAN-92 + } 2.5 \mathrm{mM} \mathrm{KI} \\
+10 \mathrm{mM} \text { urotropine }\end{array}$ & 0.68 & 83 & 0.47 & 134 & 0.35 & 249 \\
\hline \multicolumn{7}{|c|}{$80^{\circ} \mathrm{C}$} \\
\hline $2.5 \mathrm{mM}$ IFKhAN-92 + $2.5 \mathrm{mM} \mathrm{KI}$ & 1.0 & 297 & 1.1 & 185 & 1.0 & 265 \\
\hline $\begin{array}{c}2.5 \mathrm{mM} \text { IFKhAN-92 + } 2.5 \mathrm{mM} \mathrm{KI} \\
+10 \mathrm{mM} \text { urotropine }\end{array}$ & 1.1 & 270 & 0.80 & 255 & 0.81 & 327 \\
\hline \multicolumn{7}{|c|}{$100^{\circ} \mathrm{C}$} \\
\hline $5 \mathrm{mM}$ IFKhAN -92 & 382 & 1.8 & 408 & 2.1 & 436 & 2.0 \\
\hline $5 \mathrm{mM} \mathrm{KI}$ & 2.9 & 243 & 3.2 & 274 & 2.7 & 315 \\
\hline $2.5 \mathrm{mM}$ IFKhAN-92 + $2.5 \mathrm{mM} \mathrm{KI}$ & 3.8 & 186 & 2.7 & 325 & 2.5 & 340 \\
\hline 15 mM IFKhAN-92 & 188 & 3.8 & 197 & 4.5 & 249 & 3.4 \\
\hline $15 \mathrm{mM}$ urotropine & 566 & 1.2 & 686 & 1.3 & 617 & 1.4 \\
\hline $15 \mathrm{mM} \mathrm{KI}$ & 2.9 & 243 & 2.4 & 365 & 2.0 & 426 \\
\hline $2.5 \mathrm{mM}$ IFKHAN-92+2.5 mM KI & 1.6 & 441 & 1.5 & 585 & 1.4 & 608 \\
\hline
\end{tabular}




\section{Test duration}

\begin{tabular}{|c|c|c|c|c|c|c|}
\hline \multirow[t]{2}{*}{ Inhibitor } & \multicolumn{2}{|c|}{$0.5 \mathrm{~h}$} & \multicolumn{2}{|c|}{$1.0 \mathrm{~h}$} & \multicolumn{2}{|c|}{$2.0 \mathrm{~h}$} \\
\hline & $\boldsymbol{k}$ & $\gamma$ & $\boldsymbol{k}$ & $\gamma$ & $\boldsymbol{k}$ & $\gamma$ \\
\hline \multicolumn{7}{|l|}{$+10 \mathrm{mM}$ urotropine } \\
\hline $\begin{array}{c}5 \mathrm{mM} \text { IFKhAN-92 + } 5 \mathrm{mM} \mathrm{KI} \\
+20 \mathrm{mM} \text { urotropine }\end{array}$ & 2.1 & 336 & 2.6 & 337 & 1.5 & 567 \\
\hline \multicolumn{7}{|c|}{$120^{\circ} \mathrm{C}$} \\
\hline $2.5 \mathrm{mM}$ IFKhAN-92 + $2.5 \mathrm{mM} \mathrm{KI}$ & 5.0 & 234 & 4.9 & 263 & 6.5 & 140 \\
\hline $5 \mathrm{mM}$ IFKhAN-92 + $5 \mathrm{mM} \mathrm{KI}$ & 0.96 & 1219 & 1.8 & 717 & 3.5 & 260 \\
\hline $\begin{array}{c}2.5 \mathrm{mM} \text { IFKhAN-92 + } 2.5 \mathrm{mM} \mathrm{KI} \\
+10 \mathrm{mM} \text { urotropine }\end{array}$ & 2.7 & 433 & 2.5 & 516 & 2.1 & 433 \\
\hline $\begin{array}{c}5 \mathrm{mM} \text { IFKhAN-92 + } 5 \mathrm{mM} \mathrm{KI} \\
+20 \mathrm{mM} \text { urotropine }\end{array}$ & 2.7 & 433 & 3.8 & 339 & 5.3 & 172 \\
\hline \multicolumn{7}{|c|}{$140^{\circ} \mathrm{C}$} \\
\hline $2.5 \mathrm{mM}$ IFKhAN-92 + $2.5 \mathrm{mM} \mathrm{KI}$ & 8.8 & 216 & 9.5 & 213 & 10 & - \\
\hline $5 \mathrm{mM}$ IFKhAN-92 + $5 \mathrm{mM} \mathrm{KI}$ & 3.2 & 594 & 7.7 & 262 & 10 & - \\
\hline $\begin{array}{c}2.5 \mathrm{mM} \text { IFKhAN-92 + } 2.5 \mathrm{mM} \mathrm{KI} \\
+10 \mathrm{mM} \text { urotropine }\end{array}$ & 9.2 & 207 & 8.7 & 232 & 6.8 & - \\
\hline $\begin{array}{c}5 \mathrm{mM} \text { IFKhAN-92 + } 5 \mathrm{mM} \mathrm{KI} \\
+20 \mathrm{mM} \text { urotropine }\end{array}$ & 3.5 & 543 & 5.4 & 374 & 6.5 & - \\
\hline \multicolumn{7}{|c|}{$160^{\circ} \mathrm{C}$} \\
\hline 2.5 mM IFKhAN-92 + 2.5 mM KI & 56 & 72 & 138 & - & 162 & - \\
\hline 5 mM IFKhAN-92 + 5 mM KI & 33 & 122 & 41 & - & 117 & - \\
\hline $\begin{array}{c}2.5 \mathrm{mM} \text { IFKhAN-92 + } 2.5 \mathrm{mM} \mathrm{KI} \\
+10 \mathrm{mM} \text { urotropine }\end{array}$ & 21 & 191 & 30 & - & 40 & - \\
\hline $\begin{array}{c}5 \mathrm{mM} \text { IFKhAN-92 + } 5 \mathrm{mM} \mathrm{KI} \\
+20 \mathrm{mM} \text { urotropine }\end{array}$ & 20 & 201 & 15 & - & 11 & - \\
\hline \multicolumn{7}{|c|}{$180^{\circ} \mathrm{C}$} \\
\hline $\begin{array}{c}2.5 \mathrm{mM} \text { IFKhAN-92 + } 2.5 \mathrm{mM} \mathrm{KI} \\
+10 \mathrm{mM} \text { urotropine }\end{array}$ & 56 & 114 & 67 & - & 123 & - \\
\hline $\begin{array}{c}2.5 \mathrm{mM} \text { IFKhAN-92 + } 2.5 \mathrm{mM} \mathrm{KI} \\
+25 \mathrm{mM} \text { urotropine }\end{array}$ & 87 & 73 & 89 & - & 122 & - \\
\hline $\begin{array}{c}5 \mathrm{mM} \text { IFKhAN-92 + } 5 \mathrm{mM} \mathrm{KI} \\
+20 \mathrm{mM} \text { urotropine }\end{array}$ & 20 & 319 & 55 & - & 100 & - \\
\hline $\begin{array}{l}10 \mathrm{mM} \text { IFKHAN-92 + } 5 \mathrm{mM} \text { KI } \\
+15 \mathrm{mM} \text { urotropine }\end{array}$ & 80 & 80 & 80 & - & 166 & - \\
\hline
\end{tabular}




\begin{tabular}{|c|c|c|c|c|c|c|}
\hline \multirow{3}{*}{ Inhibitor } & \multicolumn{6}{|c|}{ Test duration } \\
\hline & \multicolumn{2}{|c|}{$0.5 \mathrm{~h}$} & \multicolumn{2}{|c|}{$1.0 \mathrm{~h}$} & \multicolumn{2}{|c|}{$2.0 \mathrm{~h}$} \\
\hline & $\boldsymbol{k}$ & $\gamma$ & $\boldsymbol{k}$ & $\gamma$ & $\boldsymbol{k}$ & $\gamma$ \\
\hline $\begin{array}{c}15 \mathrm{mM} \text { IFKhAN-92 + } 10 \mathrm{mM} \mathrm{KI} \\
+15 \mathrm{mM} \text { urotropine }\end{array}$ & 31 & 205 & 60 & - & 121 & - \\
\hline \multicolumn{7}{|c|}{$200^{\circ} \mathrm{C}$} \\
\hline $\begin{array}{c}2.5 \mathrm{mM} \text { IFKhAN-92 + } 2.5 \mathrm{mM} \mathrm{KI} \\
+10 \mathrm{mM} \text { urotropine }\end{array}$ & 823 & 12 & 735 & - & 513 & - \\
\hline $\begin{array}{c}5 \mathrm{mM} \text { IFKhAN-92 + } 5 \mathrm{mM} \mathrm{KI} \\
+20 \mathrm{mM} \text { urotropine }\end{array}$ & 844 & 12 & 654 & - & 455 & - \\
\hline $\begin{array}{c}10 \mathrm{mM} \text { IFKhAN-92 + } 10 \mathrm{mM} \mathrm{KI} \\
+40 \mathrm{mM} \text { urotropine }\end{array}$ & 882 & 11 & 770 & - & 744 & - \\
\hline $\begin{array}{c}20 \mathrm{mM} \text { IFKhAN-92 + } 10 \mathrm{mM} \mathrm{KI} \\
+100 \mathrm{mM} \text { urotropine }\end{array}$ & 1190 & 8.1 & 805 & - & 712 & - \\
\hline
\end{tabular}

* The change in the specimen mass during the corrosion test is below the balance sensitivity $(0.1 \mathrm{mg})$.

Steel protection in $\mathrm{H}_{2} \mathrm{SO}_{4}$ solution can be improved by using a three-component mixture based on IFKhAN-92 and KI. As an additive to this mixture, we used urotropine, which we recommended previously $[2,22]$ to increase the inhibiting effect of IFKhAN-92 in $\mathrm{HCl}$ solutions at $t>100^{\circ} \mathrm{C}$. Preliminary tests were performed using a three-component formulation with $C=30 \mathrm{mM}$. The tests performed at $180^{\circ} \mathrm{C}$ have shown that the formulation of $5 \mathrm{mM}$ IFKhAN-92 $+5 \mathrm{mM} \mathrm{KI}+20 \mathrm{mM}$ urotropine has higher efficiency than $2.5 \mathrm{mM}$ IFKhAN-92 $+2.5 \mathrm{mM} \mathrm{KI}+25 \mathrm{mM}$ urotropine or $10 \mathrm{mM}$ IFKhAN-92 + $5 \mathrm{mM} \mathrm{KI}+15 \mathrm{mM}$ urotropine. Even a mixture with a higher content of the components $(15 \mathrm{mM}$ IFKhAN-92 $+10 \mathrm{mM} \mathrm{KI}+15 \mathrm{mM}$ urotropine) is inferior to it in efficiency. Though the corrosion rate increases with time in the presence of the mixture of $5 \mathrm{mM}$ IFKhAN-92 $+5 \mathrm{mM} \mathrm{KI}+20 \mathrm{mM}$ urotropine, $k=100 \mathrm{~g} /\left(\mathrm{m}^{2} \cdot \mathrm{h}\right)$ at $t=180^{\circ} \mathrm{C}$, even according to $2 \mathrm{~h}$ tests, which is an interesting result. Further studies have shown that this mixture can be used for efficient steel protection at $t=100-180^{\circ} \mathrm{C}$ for at least $2 \mathrm{~h}$. An important property of the formulation of $5 \mathrm{mM} \mathrm{IFKhAN-92}+5 \mathrm{mM} \mathrm{KI}+20 \mathrm{mM}$ urotropine is that the protective effect is maintained in time. For example, at $160^{\circ} \mathrm{C}, k=$ $18 \mathrm{~g} /\left(\mathrm{m}^{2} \cdot \mathrm{h}\right)$ in 4 hour tests and $30 \mathrm{~g} /\left(\mathrm{m}^{2} \cdot \mathrm{h}\right)$ in 8 hour tests. Unfortunately, this formulation abruptly loses protective efficiency at $200^{\circ} \mathrm{C}$, where the minimum $k$ is $455 \mathrm{~g} /\left(\mathrm{m}^{2} \cdot \mathrm{h}\right)$ according to 2 hour tests. Attempts to increase the concentration of the components in the inhibitor mixture only decreased its protective effect.

An increase in the acid concentration in the background solution considerably increased its corrosivity. The $k$ values at $t=160^{\circ} \mathrm{C}$ are $4.0 \mathrm{~kg} /\left(\mathrm{m}^{2} \cdot \mathrm{h}\right)$ in $2 \mathrm{M} \mathrm{H}_{2} \mathrm{SO}_{4}$, $9.9 \mathrm{~kg} /\left(\mathrm{m}^{2} \cdot \mathrm{h}\right)$ in $4 \mathrm{M} \mathrm{H}_{2} \mathrm{SO}_{4}$, and $12.5 \mathrm{~kg} /\left(\mathrm{m}^{2} \cdot \mathrm{h}\right)$ in $6 \mathrm{M} \mathrm{H}_{2} \mathrm{SO}_{4}$. The three-component inhibitor mixture that we developed $\left(C_{\text {mix }}=30 \mathrm{mM}\right)$ inhibits the metal corrosion in $4 \mathrm{M}$ 
$\mathrm{H}_{2} \mathrm{SO}_{4}$ to 203,173 and $154 \mathrm{~g} /\left(\mathrm{m}^{2} \cdot \mathrm{h}\right)$ according to $0.5,1,2 \mathrm{~h}$ corrosion tests, respectively. The protective effects in $6 \mathrm{M} \mathrm{H}_{2} \mathrm{SO}_{4}$ under the same conditions are lower, namely, $k=542$, 513 , and $440 \mathrm{~g} /\left(\mathrm{m}^{2} \cdot \mathrm{h}\right)$.

The formulation of IFKhAN-92, KI and urotropine $\left(C_{\mathrm{mix}}=30 \mathrm{mM}\right)$ with a component molar ratio of $1: 1: 4$ is efficient for $08 \mathrm{Kh} 18 \mathrm{~N} 10 \mathrm{~T}$ steel protection under high-temperature corrosion conditions at $t=100-180^{\circ} \mathrm{C}$. To minimize the inhibitor consumption, it is important to study the effect of this mixture on the corrosion process at lower $C_{\text {in }}$ values. The mixture of $2.5 \mathrm{mM}$ IFKhAN-92 $+2.5 \mathrm{mM} \mathrm{KI}+10 \mathrm{mM}$ urotropine is generally less efficient in the inhibition of steel corrosion than a similar mixture with $C=30 \mathrm{mM}$, but it is sufficiently adequate even at $t=160^{\circ} \mathrm{C}$ where $k \leq 40 \mathrm{~g} /\left(\mathrm{m}^{2} \cdot \mathrm{h}\right)$. Comparison of the mixtures of $2.5 \mathrm{mM}$ IFKhAN-92 $+2.5 \mathrm{mM} \mathrm{KI}$ and $2.5 \mathrm{mM}$ IFKhAN-92 $+2.5 \mathrm{mM} \mathrm{KI}+$ $10 \mathrm{mM}$ urotropine shows that the first mixture can be more efficient an the initial stages of the corrosion process, but the second mixture ensures higher protection after $2 \mathrm{~h}$ of the corrosion process. Both formulations manifest an antagonism in the action of their components. At $t=100^{\circ} \mathrm{C}, K_{\mathrm{m}}=0.43-0.56$ for the first mixture and $0.27-0.40$ for the second one. To a large extent, the observed effect is due to the high efficiency of KI in the hindrance of chromium-nickel steel corrosion in $\mathrm{H}_{2} \mathrm{SO}_{4}$ solution. IFKhAN-92 or especially urotropine alone weakly affect the corrosion process.

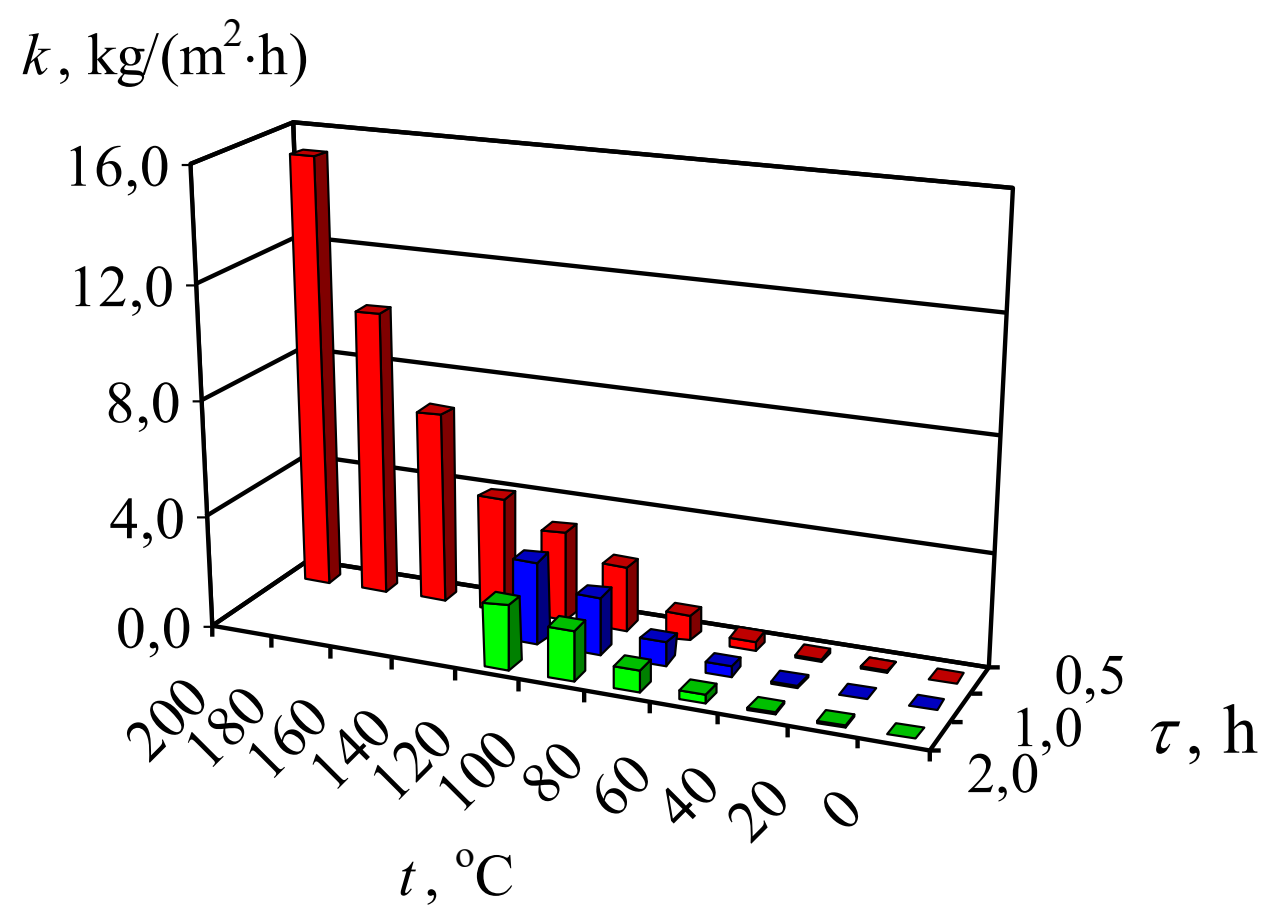

Figure 2. Corrosion rates of steel 20 in $2 \mathrm{M} \mathrm{H}_{2} \mathrm{SO}_{4}$ at various temperatures.

The three-component mixture (5 mM IFKhAN-92 $+5 \mathrm{mM} \mathrm{KI}+20 \mathrm{mM}$ urotropine) is efficient in hindering not only the corrosion of chromium-nickel steel but also that of lowcarbon steel that is even less resistant in $\mathrm{H}_{2} \mathrm{SO}_{4}$ solutions (Figure 2) at $t \leq 180^{\circ} \mathrm{C}$, where it 
provides $k \leq 200 \mathrm{~g} /\left(\mathrm{m}^{2} \cdot \mathrm{h}\right)($ Table 2$)$. It is only at $200^{\circ} \mathrm{C}$, like in the case of stainless steel, that this inhibitor mixture loses protection efficiency. At $t \leq 160^{\circ} \mathrm{C}$, this mixture slows down corrosion with time for at least $2 \mathrm{~h}$. Even at $160^{\circ} \mathrm{C}$, the $k$ value decreases with time for at least $8 \mathrm{~h}: k=6.6 \mathrm{~g} /\left(\mathrm{m}^{2} \cdot \mathrm{h}\right)$ in $4 \mathrm{~h}$ tests and $3.5 \mathrm{~g} /\left(\mathrm{m}^{2} \cdot \mathrm{h}\right)$ in $8 \mathrm{~h}$ tests, which we believe to be a unique result. In fact, the mass loss of specimens during the last $6 \mathrm{~h}$ out of the $8 \mathrm{~h}$ of the corrosion process amounts to $8 \%$ of the total mass loss.

Table 2. Corrosion rates $\left(k, \mathrm{~g} /\left(\mathrm{m}^{2} \cdot \mathrm{h}\right)\right)$ and corrosion inhibition coefficients $(\gamma)$ of steel 20 in $2 \mathrm{M} \mathrm{H}_{2} \mathrm{SO}_{4}+$ $5 \mathrm{mM}$ IFKhAN-92 $+5 \mathrm{mM} \mathrm{KI}+20 \mathrm{mM}$ urotropine at various temperatures.

\begin{tabular}{|c|c|c|c|c|c|c|}
\hline \multirow{3}{*}{ Temperature, ${ }^{\circ} \mathrm{C}$} & \multicolumn{6}{|c|}{ Test duration } \\
\hline & \multicolumn{2}{|c|}{$0.5 \mathrm{~h}$} & \multicolumn{2}{|c|}{$1.0 \mathrm{~h}$} & \multicolumn{2}{|c|}{$2.0 \mathrm{~h}$} \\
\hline & $\boldsymbol{k}$ & $\gamma$ & $\boldsymbol{k}$ & $\gamma$ & $\boldsymbol{k}$ & $\gamma$ \\
\hline 0 & 0.23 & 41 & 0.21 & 57 & 0.20 & 43 \\
\hline 20 & 0.37 & 120 & 0.27 & 130 & 0.22 & 150 \\
\hline 40 & 0.84 & 130 & 0.69 & 140 & 0.49 & 190 \\
\hline 60 & 1.6 & 220 & 1.1 & 310 & 0.78 & 400 \\
\hline 80 & 2.6 & 340 & 2.0 & 420 & 1.6 & 460 \\
\hline 100 & 4.2 & 540 & 3.2 & 640 & 2.6 & 670 \\
\hline 120 & 9.9 & 320 & 9.1 & 320 & 8.0 & 280 \\
\hline 140 & 16 & 250 & 12 & - & 11 & - \\
\hline 160 & 18 & 380 & 17 & - & 13 & - \\
\hline 180 & 100 & 100 & 130 & - & 200 & - \\
\hline 200 & 360 & 43 & 430 & - & 480 & - \\
\hline
\end{tabular}

Thus, our hypothesis about the applicability of formulations based on IFKhAN-92 for the protection of chromium-nickel steel in $\mathrm{H}_{2} \mathrm{SO}_{4}$ solutions under high-temperature corrosion conditions was confirmed. The three-component formulation of IFKhAN-92, KI and urotropine $(1: 1: 4)$ that we created reliably protects such steel at $t \leq 180^{\circ} \mathrm{C}$ in $2-4 \mathrm{M}$ $\mathrm{H}_{2} \mathrm{SO}_{4}$; in some cases, efficiency is maintained for at least $8 \mathrm{~h}$. To a large extent, the reasons for the high protective action of the inhibitor formulation developed by us lie in the uniqueness of the action mechanism of IFKhAN-92 [27], which is critically important in metal protection under high-temperature corrosion conditions. IFKhAN-92 can:

- be strongly adsorbed on a corroding metal surface;

- form a polymolecular protective layer on the metal that favors the strongest protection;

- be thermally stable in solutions of acids (without resinification);

- enhance the protective effect at high-temperature conditions when combined with other thermally stable additives. 


\section{Conclusions}

1. Chromium-nickel steel has low corrosion resistance in $\mathrm{H}_{2} \mathrm{SO}_{4}$ solutions, especially under high-temperature corrosion conditions $\left(t \geq 80^{\circ} \mathrm{C}\right)$. The formulation of IFKhAN-92 with $\mathrm{KI}(1: 1)$ allows this steel to be protected in $2 \mathrm{M} \mathrm{H}_{2} \mathrm{SO}_{4}$ at temperatures up to $140^{\circ} \mathrm{C}$, inclusive.

2. The three-component mixture of IFKhAN-92, KI and urotropine $(1: 1: 4)$ is even more efficient and hinders the corrosion of chromium-nickel steel at temperatures up to $180^{\circ} \mathrm{C}$, inclusive. This mixture can maintain its protective effect in the acid solution for at least $8 \mathrm{~h}$.

3. The formulation of IFKhAN-92, KI and urotropine $(1: 1: 4)$ also reliably protects low-carbon steel in $2 \mathrm{M} \mathrm{H}_{2} \mathrm{SO}_{4}$ at temperatures up to $180^{\circ} \mathrm{C}$, inclusive. The corrosion of steel in acid solution slows down with time in the presence of this mixture.

\section{Acknowledgements}

This study was financially supported by the Russian Foundation for Basic Research and the Government of the Kaluga Region (Project no. 14-43-03037).

\section{References}

1. N.I. Podobaev and V.V. Vasil'ev, in Ingibitory korrozii metallov. Sbornik No. 3 (Metal Corrosion Inhibitors. Vol. 3), MGPI, Moscow, 1969, 72 (in Russian).

2. Ya.G. Avdeev, A.Yu. Luchkin, Yu.I. Kuznetsov, I.G. Gorichev and M.V. Tyurina, Korroz.: mater., zashch., 2011, no. 10, 26 (in Russian).

3. Ya.G. Avdeev and Yu.I. Kuznetsov, Russ. Chem. Rev., 2012, 81, no. 12, 1133. doi: 10.1070/RC2012v081n12ABEH004292

4. Ya.G. Avdeev, Protection of Metals and Physical Chemistry of Surfaces, 2015, 51, no. 7, 1140. doi: 10.1134/S2070205115070023

5. V.N. Glushchenko and M.A. Silin, Neftepromyslovaya khimiya. Vol. 4. Kislotnaya obrabotka skvazyn (Oilfield chemistry. Vol. 4. Matrix acidizing), Ed. I.T. Mishchenko, Intercontact Nauka, Moscow, 2010, 703 pp. (in Russian).

6. M. Finšgar and J. Jackson, Corros. Sci., 2014, 86, 17.

7. G. Schmitt, Br. Corros. J., 1984, 19, no. 4, 165.

8. W.W. Frenier and D.G. Hill, in Reviews on Corrosion Inhibitor Science and Technology, ed. A. Raman, USA, Houston, Texas: NACE International, 2004, V. 3. 6-1-6-40.

9. A. Singh and M.A. Quraishi, J. Mater. Environ. Sci., 2015, 6, no. 1, 224.

10. B.R. Keeney and J.W. Johnson, US Patent 3,773,465, Halliburton Company, Duncan, Okla, 1973.

11. M.L. Walker, US Patent 4,498,997, Halliburton Company, Duncan, Okla, 1985.

12. D.G. Hill and H. Romijn, in Conference Paper: Corrosion, 2000, 26-31 March, Orlando, Florida, NACE International, NACE-00342. 
13. F.B. Growcock, W.W. Frenier and P.A. Andreozzi, Corrosion, 1989, 45, no. 12, 1007.

14. W.W. Frenier, US Patent 5,096,618, Dowell Schlumberger Incorporated, Tulsa, Okla, 1992.

15. R.J. Jasinski and W.W. Frenier, US Patent 5,120,471, Dowell Schlumberger Incorporated, Tulsa, Okla, 1992.

16. Ya.G. Avdeev, A.Yu. Luchkin and Yu.I. Kuznetsov, Korroz.: mater., zashch., 2012, no. 10, 23 (in Russian).

17. Ya.G. Avdeev, A.Yu. Luchkin, Yu.I. Kuznetsov, L.P. Kazansky and Yu.E. Pronin, Korroz.: mater., zashch., 2012, no. 11, 20 (in Russian).

18. Ya.G. Avdeev, A.Yu. Luchkin, M.V. Tyurina and Yu.I. Kuznetsov, Korroz.: mater., zashch., 2015, no. 1, 23 (in Russian).

19. Ya.G. Avdeev, M.V. Tyurina, Yu.I. Kuznetsov, Yu.E. Pronin and L.P. Kazansky, Korroz.: mater., zashch., 2013, no. 6, 17 (in Russian).

20. Ya.G. Avdeev, P.A. Belinskii, Yu.I. Kuznetsov and O.O. Zel', Prot. Met. Phys. Chem. Surf., 2010, 46, no. 7, 782. doi: 10.1134/S2070205110070087

21. Ya.G. Avdeev, A.Yu. Luchkin, Yu.I. Kuznetsov, I.G. Gorichev and M.V. Tyurina, Korroz.: mater., zashch., 2011, no. 8, 20 (in Russian).

22. Ya.G. Avdeev and A.Yu. Luchkin, Int. J. Corros. Scale Inhib., 2013, 2, no. 1, 53. doi: 10.17675/2305-6894-2013-2-1-053-066

23. Ya.G. Avdeev, D.S. Kuznetsov, M.V. Tyurina and M.A. Chekulaev, Int. J. Corros. Scale Inhib., 2015, 4, no. 2, 146. doi: 10.17675/2305-6894-2015-4-1-146-161

24. Ya.G. Avdeev, L.V. Frolova, D.S. Kuznetsov, M.V. Tyurina and M.A. Chekulaev, Int. J. Corros. Scale Inhib., 2016, 5, no. 2, 147. doi: 10.17675/2305-6894-2016-5-2-4

25. Ya.G. Avdeev, L.V. Frolova, D.S. Kuznetsov, M.V. Tyurina and M.A. Chekulaev, Int. J. Corros. Scale Inhib., 2016, 5, no. 2, 147. doi: $10.17675 / 2305-6894-2016-5-2-4$

26. Yu.I. Kuznetsov, Russ. Chem. Rev., 2004, 73, no. 1, 75. doi: 10.1070/RC2004v073n01ABEH000864

27. Ya.G. Avdeev, Zashchita metallov ot kislotnoy korrozii nenasyschennymi organicheskimi soedineniyami i azolami pri povyshennyh temperaturah. Avtoreferat dissernatsii doktora khimicheskih nauk. (Protection of metals from high-temperature acid corrosion by unsaturated organic compounds and azoles. Abstract of the Doctor of science dissertation), A.N. Frumkin Institute of Physical Chemistry and Electrochemistry, Moscow, 2013, 46 pp. (in Russian). 